\title{
Learning in Public Sector Organizations: A Theory of Action Approach
}

\author{
Max Visser • Kim Van der Togt
}

Published online: 15 March 2015

(C) The Author(s) 2015. This article is published with open access at Springerlink.com

\begin{abstract}
The importance of learning has since long been acknowledged for both business and public sector organizations. However, learning theory and research have tended to neglect the differences between these organizations, and to develop in separate and unrelated directions. To address these developments, this paper purports, first, to develop a theoretical framework that integrates various concepts from the fields of public policy learning and organizational learning, and that is specifically directed at public sector organizations. Second, the paper purports to illustrate the utility of this framework by applying it to policy-making in a Dutch municipality, the Pegasustown prostitution case.
\end{abstract}

Keywords Organizational learning $\cdot$ Public policy learning $\cdot$ Municipal decision-making - Theory of action

\section{Introduction}

The importance of learning in and by organizations has since long been recognized by organization scientists. In particular in the last two decades interest in organizational learning has been growing, as evidenced by a continuously increasing output in journals and books and an increasing number of reviews of the field (e.g., Argote 2011; Rashman et al. 2009; Shipton 2006).

While in general the main thrust of organizational learning research has been directed at business organizations, in the last 15 years learning in public sector organizations (hereafter PSOs) increasingly has received attention (Gilardi and Radaelli 2012; Maden 2012; Rashman et al. 2009). Following trends towards "Reinventing government" and "New public management," PSOs increasingly face public and political pressures to become more efficient and effective in their public services

M. Visser $(\bowtie) \cdot$ K. Van der Togt

Institute for Management Research, Radboud University, P.O. Box 9108, 6500 HK Nijmegen,

The Netherlands

e-mail: m.visser@fm.ru.nl

URL: http://www.ru.nl/fm/visser 
delivery and more transparent and accountable in their administrative processes (Dent et al. 2007; Dilworth 1996; Osborne and Gaebler 1992). To achieve all this, learning is more and more being considered as an important requirement for PSOs (Betts and Holden 2003; Bovens et al. 2008; Brown and Brudney 2003; Greiling and Halachmi 2013; Schofield and Sausman 2004).

However, there are important differences between business and public sector organizations that impact the ways in which these organizations can learn. Business organizations generally work under market conditions, in which profit, sales and expenditure figures constitute a fairly small set of relatively simple and straightforward indicators guiding decision-making and learning. PSOs generally work under bureaucratic or hybrid conditions, in which departmental governance, political rules, regulations and conflicting pressures, sudden public events, annual budgets and privatepublic interdependencies constitute a fairly large set of relatively complex and ambiguous indicators guiding decision-making and learning (Busenberg 2001; Dekker and Hansen 2004; Mintzberg 1996; Rashman et al. 2009).

Following these differences, scientists in the field of public administration have been more interested in public policy learning than in organizational learning (Bennett and Howlett 1992; Hall 1993; Browne and Wildavsky 1984; Howlett 2012). Although theory and research on public policy and organizational learning thus developed along separate lines, policy researchers generally were aware of the importance of organizations for policy learning, as is, for example, evidenced in the concepts of the "self evaluating organization" (Wildavsky 1972; Boyne et al. 2004), and more recently the neo-Pragmatist "experimentalist organization" (Evans 2000; Sabel and Simon 2011; Sabel and Zeitlin 2012; Zeitlin 2011).

This division between organizational and public policy learning theory and research reflects wider differences in the social science community at large. While much of the pioneering work in the fields of business administration and organization theory originated in public organizations (e.g., Simon, Selznick, Crozier), in the past three decades scientists in these fields have tended to lose interest in public organizations and public problems. At the same time scientists in the field of public administration have tended to isolate themselves from the larger world of mainstream organization theory (Kelman 2005, 2007; Kochan et al. 2009; Schofield 2001, 2004).

This division has had various negative consequences for the field of learning. First, it has sometimes led to an uniform and uncritical application of organization learning theories to business and public organizations, without taking into account the profound differences between the two (Dekker and Hansen 2004; Mintzberg 1996). Further, it has sometimes led to separate but comparable developments in theory building, where scientists at one side of the divide declined to build on theoretical advances at the other side (Busenberg 2001; Kelman 2005, 2007; Schofield 2004). Finally, with a few exceptions theories of policy learning and organizational learning seldom have been related to one another or analyzed from a common perspective (Common 2004; Gilardi and Radaelli 2012; Grin and Loeber 2007).

To address some of these negative consequences and to contribute to some degree of closure of the observed public-business division, the first purpose of this paper is to develop a theoretical framework that appears capable of incorporating and accommodating various concepts from the fields of public policy learning and organizational learning and that is specifically directed at public sector organizations. The second 
purpose of this paper is to illustrate the applicability and utility of this framework by applying it to an instance of policy-making in a Dutch municipality, the Pegasustown prostitution case. Finally, the paper ends with discussion and conclusions.

\section{Learning in Public Sector Organizations: A Framework}

Because the fields of public policy and organizational learning often have been characterized as having a high amount of conceptual diversity and proliferation (Shipton 2006; Tosey et al. 2012; Visser 2007), we have decided to adopt an existing theoretical framework, rather than invent a new one. For several reasons, we have selected the theory of action approach by Argyris and Schön (1974, 1978, 1996). First, Argyris and Schön were among the first organization scientists to emphasize the necessity of learning for PSOs, to provide theoretical guidelines for this and to work in practice with PSOs (Argyris 1976, 1980; Rein and Schön 1991; Schön 1971, 1975, 1979; 1983). Consequently, their approach appears to accommodate the differences between business organizations and PSOs in the nature and number of values that have to be attended to, and in the contested, political nature of the learning that takes place. Following this, their approach seems among the few to be in fairly good currency in business administration (Argote 2011; Easterby-Smith and Lyles 2003, 2011; EasterbySmith et al. 2004; Visser 2007), and in public administration (Browne and Wildavsky 1984; Duijn et al. 2010; Grin and Loeber 2007; In 't Veld 1991; Kim et al. 2013; Kolibra and Lathrop 2007; Maden 2012; Leeuw and Sonnichsen 1994; Van Dooren 2011).

Central to Argyris and Schön's approach is the relationship between knowledge and action. They consider integrating thought with action as the key challenge facing "all human beings... [who] need to become more competent in taking action and simultaneously reflecting on this action to learn from it" (Argyris and Schön 1974, p. 4). Central to this endeavor are theories of action, which have the general form: "in situation $\mathrm{S}$, if you want to achieve consequence $C$, under assumptions $\mathrm{a}_{1} \ldots \mathrm{a}_{\mathrm{n}}$, do $\mathrm{A}$ " (Argyris and Schön 1974, p. 6). Assumptions $\mathrm{a}_{1} \ldots \mathrm{a}_{\mathrm{n}}$ constitute a model of the world, in which it is probable that action strategy A will lead to consequence $\mathrm{C}$ in situation $\mathrm{S}$. Consequence $\mathrm{C}$ refers to all kinds of purposes and goals which an actor may aspire to achieve. Besides these elements, theories of action contain governing variables. These are deeper lying norms, values and core beliefs of persons and organizations that make consequence $\mathrm{C}$ desirable or worthwhile to achieve (Fig. 1).

Different from business organizations, for PSOs the consequences they intend to achieve are primarily policy goals and purposes. We define a policy as an elaborate theory of action at the organizational level of a PSO. Such a policy theory of action is

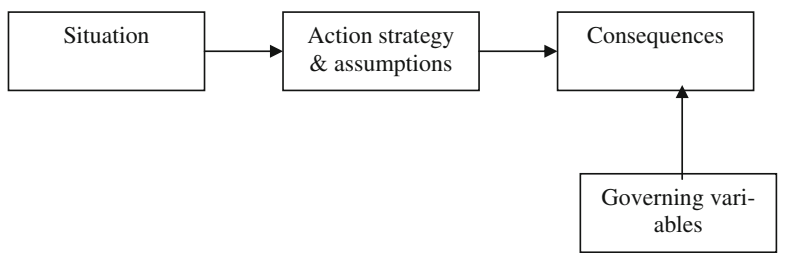

Fig. 1 Theory of action 
comparable to a policy belief system (Grin and Loeber 2007; Jenkins-Smith and Sabatier 1993; Koppenjan and Hufen 1991), policy paradigm (Bennett and Howlett 1992; Hall 1993), and policy frame (In 't Veld 1991; Rein and Schön 1991).

Argyris and Schön distinguish between espoused theory of action and theory in use. For persons espoused theory refers to the theory they say they will follow when queried about it. For organizations espoused theory refers to the theory that persons, acting for the organization, formally announce the organization will follow, and also to the theory that the organization formally states it will follow, for example in policy plans, strategic documents, rules and procedures. Theory in use, on the other hand, refers to the theory that persons and organizations actually follow in their daily actions, and which may reconstructed on the basis of observation of those actions. These two theories may or may not coincide, and persons or organizations may or may not be aware of possible inconsistencies between the two.

The development of espoused policy theory starts in the political domain, i.e., as the formal promulgation of laws and regulatory rules by acts of legislative bodies. These laws and rules contain the aspired policy consequences, assumptions, instruments and action strategies, tied together in more or less coherent ways with governing variables, the deeper lying norms, values and core beliefs (Hoogerwerf 1990; Sabatier and Jenkins-Smith 1993). When PSOs are charged with the execution of these formal laws and regulations, they first develop their own espoused policy theory on the basis of the policy theory they view as underlying these formal laws and regulations. Gradually however, their espoused policy theory acquires an in use character, as it moves forward in the direction of concrete execution.

We define policy implementation as the final phase in this transition. The policy theory in use guides the ways in which concrete actions are devised for concrete situations and carried out in ways that lead to tangible consequences among policy subjects. Such consequences become most visible at the street-level of bureaucracy (Evans and Harris 2004; Lipsky 1980), when behavior of policy subjects is changed in accordance with policy goals or not. Policy theory in use may or may not differ from espoused policy theory, but the way in which it is implemented ultimately is decisive for the success or failure of the policy theory involved (Browne and Wildavsky 1984; Schofield 2001; Schön 1979; Wildavsky 1972).

Learning starts when actual consequences of an action strategy do not correspond to expected consequences. This discrepancy between expectation and result is considered an error and leads to a problematic situation, which calls for a period of joint and collaborative reflection and inquiry by the acting organizational members (Argyris and Schön 1978, 1996; Schön 1983). Such joint reflection and inquiry may proceed on a more informal or a more formal basis. For PSOs the latter case often involves policy evaluation, defined here as a formal, prolonged and structured form of inquiry and reflection on the ways in which action strategies in policy theory in use have led to expected, or more often to unexpected, consequences (Duijn et al. 2010; Leeuw and Sonnichsen 1994; Minnett 1999; Rist 1994; Van der Knaap 2004).

We define learning as the "detection and correction of error," on the basis of (formal and informal) joint reflection and inquiry (Argyris and Schön 1978, p. 2). It may first be accomplished through single-loop learning. Here organization members mitigate the discrepancy between expected and actual consequences by adjusting the relationships between situation, action strategy, assumptions and consequences, without questioning 
the governing variables, the deeper lying norms, values and core beliefs that make consequences important to attain (Fig. 2). This type of learning is comparable to first order learning (Hall 1993; In 't Veld 1991), technical learning (Fiorino 2001), instrumental learning (Gilardi and Radaelli 2012; May 1992), policy-oriented learning (Howlett 2012; Jenkins-Smith and Sabatier 1993), and improvement learning (Van der Knaap 2004).

However, if after several cycles of single loop learning errors still persist, a more comprehensive and incisive form of error detection and correction may be necessary. This is accomplished through double loop learning. Here the governing variables, the deeper lying norms, values and core beliefs that make consequences important to attain, are subject to joint reflection and inquiry and, if necessary, changed. When these norms, values and core beliefs change, a whole set of new consequences may come into being, leading to all kinds of new relationships between situations, action strategies, assumptions and consequences (Fig. 3). This type of learning is comparable to second order learning (Hall 1993; In 't Veld 1991), conceptual learning (Fiorino 2001), social learning (Gilardi and Radaelli 2012; May 1992), substantive learning (Ventriss and Luke 1988), and innovative learning (Van der Knaap 2004).

Organizations differ in the degree to which errors are surfaced and put to reflection and inquiry. To account for these differences, Argyris and Schön $(1978,1996)$ have inquired into the ways in which the learning climate (or behavioral world) of an organization inhibits or promotes reflection and inquiry, and thus learning. Based on their action research and intervention experiences, Argyris and Schön assert that most organizations are driven by a Model O-I learning climate. This model is characterized by a closed attitude among individuals and defensive routines in the organization as a whole, exemplified in a general atmosphere of distrust and lack of respect between managers and employees, blocked communication, contested problem definitions, and "naming and blaming" in the case of errors (Bovens et al. 2008; Dilworth 1996; Howlett 2012; Jenkins-Smith and Sabatier 1993). All this conspires to make collaborative reflection on and inquiry into the causes of error, and hence learning, hard to achieve.

As an alternative to Model O-I and to enable collaborative reflection and inquiry, Argyris and Schön $(1978,1996)$ advocate a Model O-II learning climate. This model is characterized by an open attitude among individuals and a productive learning climate in the organization as a whole, exemplified in a general atmosphere of trust and respect between managers and employees, open communication, fact-based problem definitions, and openness towards errors (Bovens et al. 2008; Dilworth 1996; Jenkins-Smith and Sabatier 1993; Wildavsky 1972). Argyris and Schön regard Model O-II as a crucial

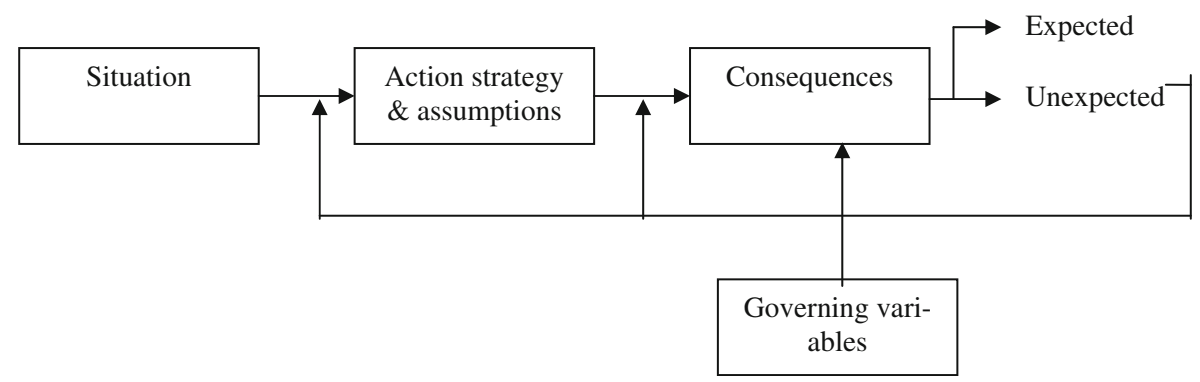

Fig. 2 Single loop Learning 


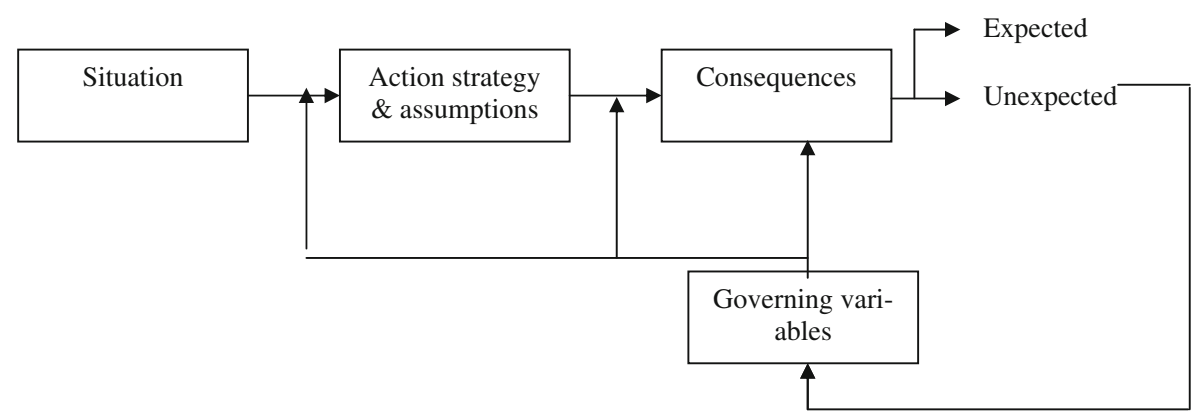

Fig. 3 Double loop Learning

condition for double-loop learning, and double loop learning in its turn as a crucial condition for organizational survival in the long run. Model O-II organizations, however, are rarely found in practice, and often external interventions are necessary to create a productive learning climate.

Finally, Argyris and Schön (1978) link individual learning to organizational learning by pointing out that, by virtue of delegated responsibilities, some employees are empowered to speak and act on behalf of the whole organization, not only in top positions, but in every role or function dealing with external relations or subjects. Those employees learn when they experience the discrepancy between consequences of an action, expected on the basis of organizational theory of action, and actual consequences. If the organization as a whole is to learn, then the corrective actions these employees undertake on the basis of reflection and inquiry into that discrepancy should become embedded in the espoused organizational theory of action (e.g., policy plans, strategic documents, rules and procedures), and then in the organizational theory in use guiding daily actions.

For PSOs the room for empowerment, and thus for learning at both individual and organizational levels, may be more circumscribed than for business organizations. When policies as implemented deviate too much from policies as espoused by the political authorities, issues of democratic responsiveness and accountability arise (Bovens et al. 2008; Mintzberg 1996). While "street-level bureaucrats" may want empowerment and administrative discretion to adapt policy rules to concrete client needs and field developments, political authorities and the public-at-large may want predictability and uniformity in the provision of public services, thus curtailing discretion (Bovens and Zouridis 2002).

In summary, the framework for public sector organizational learning centers on the concepts of policy theory of action, espoused policy theory, policy theory in use, single loop learning, double loop learning, Model O-I and Model O-II learning climate. In the next section we will attempt to illustrate the applicability and utility of this framework by applying it to a case of municipal policy-making, the Pegasustown prostitution case. ${ }^{1}$

\footnotetext{
${ }^{1}$ The empirical data for this case were collected in Spring 2008. The data collection involved a detailed content analysis of relevant municipal policy documents, news paper articles and court verdicts, and a round of semi-structured interviews with municipal council members and aldermen from different political backgrounds, who were all actively involved in the policy changes in the case. Further background information was found in a dissertation by Gorgels (1993), who researched prostitution policy-making and implementation in Pegasustown and five other Dutch municipalities.
} 


\section{Public Sector Organizational Learning: The Pegasustown Prostitution Case}

The municipality of Pegasustown includes the city of Pegasustown and a few suburbs, numbers a total of 141.000 inhabitants, and is located in the Eastern part of the Netherlands. Dutch municipalities like Pegasustown are governed by a Board of Mayor and Aldermen (hereafter the Board), who in the formulation and implementation of policies are supported by the municipal administrative service. The Board is politically accountable and responsible to the Municipal Council (hereafter the Council), elected every 4 years by the eligible electorate of the municipality.

Prostitution was officially illegal in the Netherlands since 1911, but it was tolerated as long as prostitution business owners and prostitutes adhered to the rules and regulations set by local authorities. In the 1960s prostitution became more openly tolerated than before, until it finally became legalized in 2000. The city of Pegasustown housed a thriving prostitution business in its so-called Red Quarter since the mid 1960s. Although this business caused much annoyance and trouble for the Red Quarter inhabitants not involved in it, the number of prostitution windows and houses was allowed to expand during the early 1970s, in line with the permissive atmosphere of that time. However, from the late 1970s onwards the amount of trouble and nuisance associated with prostitution reached unprecedented heights, due to increasing drug abuse, drugs-related crime, street soliciting and intensive trafficking. Activist Red Quarter inhabitants organized themselves in a Work Group Red Quarter and staged various large-scale protest meetings, which received broad media coverage and gradually propelled Board and Council into action.

As a first step, in the late 1970s the prostitution windows were concentrated in only one part of the Red Quarter. This policy measure had some effect, but after the protest meetings, the Working Group Red Quarter continued to pressure the Council to put an end to window prostitution altogether, and the Council made implicit promises to do so. In response to those pressures and also in line with the less permissive atmosphere of the 1980s, consensus grew in the Council that "prostitution does not belong in a residential area." However, Board and Council sensed that they could not close down the prostitution business in a fortnight, lest they be confronted with financial claims by the prostitution business owners. Therefore they anticipated future developments by promising these owners an alternative location at an "Eros Center," to be developed in the industrial area of Pegasustown.

As a consequence, in the 1980s and early 1990s further policy measures were taken. Spots for street soliciting were relocated from the Red Quarter to an isolated zone in the industrial area of Pegasustown, where authorities could exert more control over the situation. Further several hotels and cafes, suspected of involvement in drugs related crime, were closed and drugs addicted junks were taken off the streets. Trafficking was regulated by installing one-way direction streets and closing off the whole quarter for cars at night. These policy measures went a long way in relieving the problems of the inhabitants in the Red Quarter, although the Work Group Red Quarter remained adamant in battling prostitution.

Not unexpectedly, other groups in and outside the Red Quarter were less content with these developments. The prostitutes feared the loss of their familiar work places and the loss of anonymity that relocation would bring. Many of them were involved in formally illegal activities, such as the use of hard drugs and illegal residence in the Netherlands, and consequently were not very keen on too much municipal involvement in 
their work area. They did, however, organize themselves in an interest group, but since they were never involved in municipal policy-making, they remained relatively politically powerless. The visitors of the prostitutes also were not happy with these developments, but for understandable reasons they could not raise their voices in an organized manner. One group that did organize itself effectively was the prostitution business owners. They brought several law suits against the Pegasustown municipality, but they lost all of them and early 2006 the last prostitution house in the Red Quarter was closed down.

A group outside the Red Quarter showing discontent with the process was the industrial business owners in Pegasustown's industrial area. Not only was the new spot for street soliciting practically put on their doorstep, their area also already housed a drugs rehabilitation center. Initially the industry owners were promised by the Council that the new Eros Center would not be planned in their area, but this promise could not be formally held. In the meantime, however, this Eros Center still has not materialized. The prostitute business owners were invited by Board and Council to propose their own ideas for that Center, be it within several constraints regarding the visibility of the Center, the number of windows and the regulation of traffic. Until today they have not been able to come up with a proposal, and, given the resistance of the industrial business owners, the Board has not been particularly anxious to receive one, according to one respondent.

In terms of the learning framework developed in this paper, it may be argued that in the early 1970s the Pegasustown policy theory in use was one of "laissez-faire" and tacit recognition of prostitution, although its espoused policy theory, as laid down in formal municipal rules and regulations, was stricter and less permissive on this subject. When in the course of that decade the situation escalated and provoked large-scale protests, municipal policy theory in use changed more in the direction of the espoused policy theory. The desired consequence of policy theory in use now became the reduction of the problems and nuisance associated with prostitution in the Red Quarter, on the basis of a deeper-lying and increasingly shared governing variable that "prostitution does not belong in a residential area." The various promises the Council made to different groups constitute a less formal espoused policy theory, but here the different groups saw to it that this particular espoused theory was put to use.

These changes in policy theory in use seem to have been the result of single loop learning, rather than double loop learning. The first policy measures of the Board and Council only partly achieved the expected consequence of reducing the prostitutionrelated problems in the Red Quarter. The continuing pressures of the Working Group Red Quarter made it clear to Board and Council that this consequence only could be achieved by taking more drastic policy measures, i.e., by changing action strategies and assumptions in the direction of full abolishment of window prostitution in the Red Quarter and its relocation to a less populated area of the city. With the closure of the last prostitution window in 2006, this consequence at last has been achieved.

The respondents hold somewhat different views on this course of events, though. Two respondents indicate that the first policy measures in fact went a long way in reducing nuisance and problems in the Red Quarter, almost to the extent that relocation of window prostitution probably would not have been necessary. One of these respondents even argues that the Working Group Red Quarter was at least partly motivated by financial motives. All active Working Group members owned one or more houses in the Red Quarter, and they all stood to gain much by the total abolishment of prostitution in their neighborhood. Another respondent disagrees with this view and argues that the 
amount of problems and nuisance was still high enough to legitimize the total relocation of the prostitution business.

Double loop learning does not appear to have taken place. For this type of learning it is necessary that the governing variables that make consequences worthwhile to achieve are subject to inquiry and changed. However, the governing variable that "prostitution does not belong in a residential area" became generally accepted by the Council in the early 1980s and continues to do so in the present. In the beginning, however, Board and Council were not ready to accept the ultimate consequences of this variable, because, as one respondent puts it, "everybody knew that relocation of the whole prostitution business certainly would mean lots of problems, legal procedures, financial risks, and media attention." Only when the Working Group Red Quarter increased the pressure on the Council did it change its policy towards relocation. At the same time the Council attempted to avoid too many frictions with the prostitution business owners, in which it did not succeed. The external pressures in this case thus reinforced existing governing variables and in this way accelerated single loop learning by Board and Council.

The learning climate in this case may be characterized as predominantly Model O-I, although a few Model O-II characteristics can be discerned. Regarding Model O-II, one respondent observes that in the whole period between the early 1980s and today Board and Council "looked after each other," because of the tenacity of the problems and the toughness of the decisions involved. Although some political games were played once in a while, on the whole decision-making occurred in an atmosphere of mutual regard and relative openness between Board and Council. Another respondent notes that the different political backgrounds of the Council members never caused much tension because all members highly valued consensus. However, he thinks that some tension would have spurred more debate between the members, which in turn might have led to better decisions in some of the events described in this paper.

Regarding Model O-I, two factors seem to have been influential, according to all respondents. First, they all point at the pervasive influence of media attention in the whole case. The broad media coverage of the protests and grievances against prostitution-related problems in the Red Quarter put decision-making in the Council under severe pressure. Many Council members saw the media attention as a fine opportunity to have their "one minute of fame," and, not wanting to appear unsympathetic to the inhabitants' complaints in public, made implicit promises to remove prostitution from the Red Quarter. When later doubts arose in the Council about the wisdom of a wholesale relocation of the prostitution business in the light of expected damage claims and other financial consequences, many Council members were reluctant to rescind their promise, because they feared to be exposed in the media as untrustworthy. Defensive "face saving" became more important than an open-minded inquiry into new possible ways of action.

Second and related to the first factor, the three implicit and explicit promises made by the Council to Red Quarter inhabitants, prostitution business owners and industry owners made it difficult for Board and Council to act on new information or to reflect on the wisdom of adopted policy measures on the basis of open-minded inquiry. The Working Group Red Quarter used the implicit promise to remove prostitution to keep pressure on the Council, aided by media attention. The prostitution business owners used the promise of a new Eros Center in several court proceedings to argue for a moratorium on their forced relocation from the Red Quarter. Since Pegasustown had not arranged for a suitable 
new prostitution location, their forced relocation was unlawful, an argument which the Court declined to accept, however. Finally, the industry owners intended to keep the Council to its initial promise of "no Eros Center in their area," which paradoxically helped the prostitution business owners in building their case in Court.

\section{Conclusions and Discussion}

Three conclusions may be drawn on the basis of this illustrative application of the learning framework to the Pegasustown prostitution case. First, for PSOs the different elements of this framework more often constitute contested areas of public debate than neatly ordered and detectable action and performance indicators. The degree to which the municipal authorities succeeded in achieving the consequence of reducing prostitution-related problems in the Red Quarter, and the question which action strategies and assumptions were necessary for that achievement were subject to different, intensely held views inside and outside the Council.

Second, depending upon the amount of public attention to a certain policy domain, PSOs can allow espoused policy theory to deviate only to a small extent from policy theory in use in that domain. Commitments and promises made in public that cannot be put into policy theory in use are likely to raise questions about democratic accountability and reliability in the media and the public, and they are also likely to be used against the policy-making authorities in court proceedings.

Third, the learning in this case appears to have been more single than double loop, in a learning climate that appears to have been more Model O-I than O-II. The broad media coverage and attention in this case, together with the pressures of the various groups involved and publicly announced promises and commitments, generally militated against a productive reflection on the wisdom of existing policy measures, and an open inquiry into possible alternatives. The governing variable underlying municipal prostitution policy measures was not questioned, at any rate not by the dominant actors in this case. The prostitutes and the owners of prostitution businesses might have held different governing variables in this respect, but they were not politically able to turn the tables.

Regarding the applicability and utility of this framework, three points of discussion emanate from this paper. First, learning in PSOs cannot be separated from questions of power and influence (Betts and Holden 2003; Jenkins-Smith and Sabatier 1993). In any given policy domain different groups with different interests and different norms and values will attempt to influence the development and implementation of policy theories. They will do so by contesting existing action strategies, assumptions and consequences, and by emphasizing different governing variables than the ones apparently underlying the policy involved. Many learning theorists do not consider these conditions very conducive to the collaborative inquiry and reflection, necessary for double loop learning or even solid single loop learning (e.g., Argyris 1976, 1980; Argyris and Schön 1978). Others, however, argue that this really depends upon the quality of the political decision-making process and the commitment of politicians towards policy theories in use (e.g., Dekker and Hansen 2004). The prostitution case seems to support the latter view: the more politicians give in to and honor competing demands by different interest groups, the less room they create for themselves for open-minded reflection and inquiry, and hence for double loop learning. 
Second, the depth of change in policy theories of action as a result of single and double loop learning is a point of debate in the literature. Some argue for a rather sharp binary division between both forms of learning, in which changes in governing variables appear as paradigm shifts that occur fairly independent of single loop learning results (Gilardi and Radaelli 2012; Hall 1993). Others argue that such paradigm shifts may be more characteristic of majoritarian democratic systems (like the Anglo-Saxon countries) than consociational democratic systems (like the Netherlands and most Continental European countries). In the latter systems conflicting sets of governing policy variables are less likely to gain majority support than in the former, and consequently, these conflicting sets will tend to coexist rather than dominate one another. Given this coexistence, in consociational democracies single and double loop learning results are expected to be less sharply divided and more accumulative (Grin and Loeber 2007; Helderman et al. 2005; Hemerijck and Visser 1997; Van Gestel et al. 2008). The prostitution case seems to modify the latter position in that some sets of governing variables may actually become dominant even in consociational systems, because competing sets of governing variables are only supported by politically powerless or unpopular minorities, like the prostitutes and their business owners in this case. Learning here will then be by definition of the single loop kind, since the broad agreement on the underlying governing variables is not disturbed.

Third, the nature of the relationship between political authorities and PSOs has recently been questioned on neo-Pragmatist grounds (Evans 2000; Sabel and Simon 2011; Sabel and Zeitlin 2012; Zeitlin 2011). In the face of current environmental turbulence, complexity and change, political authorities can no longer be held capable of predicting and steering environmental events on the basis of detailed hierarchical top-down command and control. Instead these authorities should set general goals, and monitor the efforts of local actors to achieve those goals by means of their own devising. The authorities should intervene only when the efforts of the latter fall short or are inadequately accounted for. PSOs should be given room to develop policies, experiment with their implementation, and to learn from one another's problem solving in the pursuance of these general goals. Although in this paper we have not differentiated between municipal political authorities and administrative services, the prostitution case seems to suggest that this neo-Pragmatist view may be unduly optimistic about the ways in which political authorities can shield themselves from public demands and emotions. Further, this view may be unduly optimistic about the amount of trust and administrative discretion politicians are inclined to lend to PSOs when it comes to implementation of publicly intensively debated and contested policies. ${ }^{2}$

Finally, this paper has some clear limitations. First of all, its empirical base is modest, which precludes far reaching conclusions and recommendations. Besides

\footnotetext{
${ }^{2}$ While the neo-Pragmatist arguments appear quite new, it may be noted here that the Prussian-German Army in the early 19th century already adopted a similar philosophy of command and control, which later became known as 'Auftragstaktik' (Visser 2008, 2010; Wilson 1989). A century later the Israeli Defense Forces came to embrace an even more decentralized form of command and control (Horowitz 1970; Van Creveld 2002). These army examples seem to suggest that hierarchical organization does not necessarily preclude learning, provided that senior commanders set broadly specified goals, give their subordinate commanders considerable discretion for independent decision-making in the pursuance of those goals, assure that they are sufficiently trained and equipped to do so, and provided that these senior commanders use the errors that invariably occur in independent decision-making as learning opportunities in an atmosphere of trust and respect (Visser 2008, 2010; Wilson 1989).
} 
document content analyses, the findings are based on a set of interviews among political actors only, where a more comprehensive design should have included Red Quarter inhabitants, prostitutes, business owners, etc.. Second, the municipality of Pegasustown has been treated as a unitary PSO, where a subdivision between political authorities and administrative services would in all probability have provided a more detailed and nuanced picture of the events in this case. Finally, the relations between the municipality and other important government agencies, like the local police force, public health and welfare agencies, have not been researched in depth, although it is highly probable that these agencies have played an important role in the implementation of prostitution-related policies.

In spite of these empirical limitations, it has proved possible to develop a framework for learning in public sector organizations that appeared capable of incorporating and accommodating various concepts from the fields of public policy learning and organizational learning and that could be illustrated by an empirical case in a meaningful way. It is hoped that in this way this paper contributes to closing some of the distance between the fields of business and public administration and to improving the effectiveness of public service organizations.

Acknowledgments We thank Paul 't Hart, Jan-Kees Helderman, Nicolette Van Gestel, Christine Teelken, Inga-Lill Johansson, Louise Fitzgerald, and the participants of Standing Work Group "Organizing the Public Sector", 26th EGOS Colloquium (Lisbon, 2010), for their stimulating and critical comments on earlier drafts of this paper.

Open Access This article is distributed under the terms of the Creative Commons Attribution License which permits any use, distribution, and reproduction in any medium, provided the original author(s) and the source are credited.

\section{References}

Argote, L. (2011). Organizational learning research: past, present and future. Management Learning, 42(4), $439-446$.

Argyris, C. (1976). Single-loop and double-loop models in research on decision-making. Administrative Science Quarterly, 21(3), 363-375.

Argyris, C. (1980). Making the undiscussable and its undiscussability discussable. Public Administration Review, 40(3), 205-213.

Argyris, C., \& Schön, D. A. (1974). Theory in practice: Increasing professional effectiveness. San Francisco: Jossey-Bass.

Argyris, C., \& Schön, D. A. (1978). Organizational learning: A theory of action perspective. Reading: Addison-Wesley.

Argyris, C., \& Schön, D. A. (1996). Organizational learning II: Theory, method and practice. Reading: Addison-Wesley.

Bennett, C. J., \& Howlett, M. (1992). The lessons of learning: reconciling theories of policy learning and policy change. Policy Sciences, 25(3), 275-294.

Betts, J., \& Holden, R. (2003). Organizational learning in a public sector organization: a case study in muddled thinking. Journal of Workplace Learning, 15(6), 280-287.

Bovens, M., \& Zouridis, S. (2002). From street-level to system-level bureaucracies: how information and communication technology is transforming administrative discretion and constitutional control. Public Administration Review, 62(2), 174-184.

Bovens, M., Schillemans, T., \& 't Hart, P. (2008). Does public accountability work? An assessment tool. Public Administration, 86(1), 225-242.

Boyne, G. A., Gould-Williams, J. S., Law, J., \& Walker, R. M. (2004). Toward the self-evaluating organization? An empirical test of the Wildavsky model. Public Administration Review, 64(4), 463-473. 
Brown, M. M., \& Brudney, J. L. (2003). Learning organizations in the public sector? A study of police agencies employing information and technology to advance knowledge. Public Administration Review, 63(1), 30-43.

Browne, A., \& Wildavsky, A. (1984). Implementation as exploration. In J. L. Pressman \& A. Wildavsky (Eds.), Implementation: How great expectations in Washington are dashed in Oakland (3rd ed., pp. 232256). Berkeley: University of California Press.

Busenberg, G. J. (2001). Learning in organizations and public policy. Journal of Public Policy, 21(2), $173-189$.

Common, R. (2004). Organizational learning in a political environment: improving policy-making in UK government. Policy Studies, 25(1), 35-49.

Dekker, S., \& Hansen, D. (2004). Learning under pressure: the effects of politicization on organizational learning in public bureaucracies. Journal of Public Administration Research and Theory, 14(2), 211-230.

Dent, M., Van Gestel, N., \& Teelken, C. (2007). Symposium on changing modes of governance in public sector organizations: action and rhetoric. Public Administration, 85(1), 1-8.

Dilworth, R. L. (1996). Institutionalizing learning organizations in the public sector. Public Productivity and Management Review, 19(4), 407-421.

Duijn, M., Rijnveld, M., \& Van Hulst, M. (2010). Meeting in the middle: joining reflection and action in complex public sector projects. Public Money and Management, 30(4), 227-233.

Easterby-Smith, M., \& Lyles, M. A. (2003). Re-reading organizational learning: selective memory, forgetting and adaptation. Academy of Management Executive, 17(2), 51-55.

Easterby-Smith, M., \& Lyles, M. A. (2011). The evolving field of organizational learning and knowledge management. In M. Easterby-Smith \& M. A. Lyles (Eds.), Handbook of organizational learning and knowledge management (2nd ed., pp. 1-20). New York: Wiley.

Easterby-Smith, M., Antonacopolou, E., Simm, D., \& Lyles, M. A. (2004). Constructing contributions to organizational learning: Argyris and the next generation. Management Learning, 35(4), 371-380.

Evans, K. G. (2000). Reclaiming John Dewey: democracy, inquiry, pragmatism and public management. Administration \& Society, 32(3), 308-328.

Evans, T., \& Harris, J. (2004). Street-level bureaucracy, social work and the (exaggerated) death of discretion. British Journal of Social Work, 34(6), 871-895.

Fiorino, D. F. (2001). Environmental policy as learning: a new view of an old landscape. Public Administration Review, 61(3), 322-334.

Gilardi, F., \& Radaelli, C. M. (2012). Governance and learning. In D. Levi-Faur (Ed.), Oxford handbook of governance (pp. 155-168). Oxford: Oxford University Press.

Gorgels, D. (1993). Hoeren, burgers en beslissers: mogelijkheden van een handelingsgericht beleid. Amsterdam: Thesis Publishers (in Dutch)

Greiling, D., \& Halachmi, A. (2013). Accountability and organizational learning in the public sector. Public Performance \& Management Review, 36(3), 380-406.

Grin, J., \& Loeber, A. (2007). Theories of policy learning: Agency, structure, and change. In F. Fischer, G. J. Miller, \& M. S. Sidney (Eds.), Handbook of public policy analysis: Theory, politics, and methods (pp. 201-219). Boca Raton: CRC Press.

Hall, P. A. (1993). Policy paradigms, social learning, and the state: the case of economic policy-making in Britain. Comparative Politics, 25(3), 275-296.

Helderman, J. K., Schut, F. T., Van der Grinten, T. E. D., \& Van de Ven, W. P. M. M. (2005). Market-oriented health care reforms and policy learning in the Netherlands. Journal of Health Politics, Policy \& Law, 30(1-2), 189-209.

Hemerijck, A., \& Visser, J. (1997). A Dutch miracle: Job growth, welfare reform and corporatism in the Netherlands. Amsterdam: Amsterdam University Press.

Hoogerwerf, A. (1990). Reconstructing policy theory. Evaluation and Program Planning, 13(3), 285-291.

Horowitz, D. (1970). Flexible responsiveness and military strategy: the case of the Israeli army. Policy Sciences, 1(2), 191-205.

Howlett, M. (2012). The lessons of failure: learning and blame avoidance in public policy-making. International Political Science Review, 33(5), 539-555.

In 't Veld, R. J. (1991). Autopoiesis, configuration and steering: Impossibility theorem or dynamic steering theory. In R. J. In 't Veld, L. Schaap, C. J. A. M. Termeer, \& M. J. W. Van Twist (Eds.), Autopoiesis and configuration theory: New approaches to societal steering (pp. 3-18). Dordrecht: Kluwer.

Jenkins-Smith, H. C., \& Sabatier, P. A. (1993). The dynamics of policy-oriented learning. In P. A. Sabatier \& H. C. Jenkins-Smith (Eds.), Policy change and learning: An advocacy coalition approach (pp. 41-56). Boulder: Westview Press.

Kelman, S. (2005). Public management needs help! Academy of Management Journal, 48(6), 967-969. 
Kelman, S. (2007). Public administration and organization studies. Academy of Management Annals, 1(1), 225-267.

Kim, H., MacDonald, R. H., \& Andersen, D. F. (2013). Simulation and managerial decision-making: a double loop learning framework. Public Administration Review, 73(2), 291-300.

Kochan, T. A., Guillen, M. F., Hunter, L. W., \& O’Mahoney, S. (2009). Introduction to the special research forum - public policy and management research: finding the common ground. Academy of Management Journal, 52(6), 1088-1100.

Kolibra, C. J., \& Lathrop, J. (2007). Inquiry as intervention: employing action research to surface intersubjective theories-in-use and support an organization's capacity to learn. Administration \& Society, 39(1), 51-76.

Koppenjan, J. F. M., \& Hufen, J. A. M. (1991). Autopoiesis, learning and governmental steering. In R. J. Int Veld, L. Schaap, C. J. A. M. Termeer, \& M. J. W. Van Twist (Eds.), Autopoiesis and configuration theory: New approaches to societal steering (pp. 171-181). Dordrecht: Kluwer.

Leeuw, F. L., \& Sonnichsen, R. C. (1994). Introduction: Evaluation and organizational learning: International perspectives. In F. L. Leeuw, R. C. Rist, \& R. C. Sonnichsen (Eds.), Can governments learn? Comparative perspectives on evaluation and organizational learning (pp. 1-13). New Brunswick: Transaction.

Lipsky, M. (1980). Street-level bureaucracy: Dilemma's of the individual in public services. New York: Russell Sage.

Maden, C. (2012). Transforming public organizations into learning organizations: a conceptual model. Public Organization Review, 12(1), 71-84.

May, P. J. (1992). Policy learning and failure. Journal of Public Policy, 12(4), 331-354.

Minnett, A. M. (1999). Internal evaluation in a self-reflective organization: one nonprofit agency's model. Evaluation and Program Planning, 22(3), 353-362.

Mintzberg, H. (1996). Managing government - governing management. Harvard Business Review, 74(3), 7583.

Osborne, D., \& Gaebler, T. (1992). Reinventing government: How the entrepreneurial spirit is transforming the public sector. Reading: Addison-Wesley.

Rashman, L., Withers, E., \& Hartley, J. (2009). Organizational learning and knowledge in public service organizations: a systematic review of the literature. International Journal of Management Reviews, 11(4), 463-494.

Rein, M., \& Schön, D. A. (1991). Frame-reflective policy discourse. In P. Wagner, C. H. Weiss, B. Wittrock, \& H. Wollmann (Eds.), Social sciences and modern states: National experiences and theoretical crossroads (pp. 262-289). Cambridge: Cambridge University Press.

Rist, R. C. (1994). The preconditions for learning: Lessons from the public sector. In F. L. Leeuw, R. C. Rist, \& R. C. Sonnichsen (Eds.), Can governments learn? Comparative perspectives on evaluation and organizational learning (pp. 189-205). New Brunswick: Transaction.

Sabatier, P. A., \& Jenkins-Smith, H. C. (1993). The advocacy coalition framework: Assessment, revisions, and implications for scholars and practitioners. In P. A. Sabatier \& H. C. Jenkins-Smith (Eds.), Policy change and learning: An advocacy coalition approach (pp. 211-239). Boulder: Westview Press.

Sabel, C. F., \& Simon, W. H. (2011). Minimalism and experimentalism in the administrative state. Georgetown Law Journal, 100(1), 53-93.

Sabel, C. F., \& Zeitlin, J. (2012). Experimentalist governance. In D. Levi-Faur (Ed.), Oxford handbook of governance (pp. 169-183). Oxford: Oxford University Press.

Schofield, J. (2001). Time for a revival? Public policy implementation: a review of the literature and an agenda for future research. International Journal of Management Reviews, 3(3), 245-263.

Schofield, J. (2004). A model of learned implementation. Public Administration, 82(2), 283-308.

Schofield, J., \& Sausman, C. (2004). Symposium on implementing public policy: learning from theory and practice: introduction. Public Administration, 82(2), 235-248.

Schön, D. A. (1971). Beyond the stable state. New York: Random House.

Schön, D. A. (1975). Deutero-learning in organizations: learning for increased effectiveness. Organizational Dynamics, 4(1), 2-16.

Schön, D. A. (1979). Public service organizations and the capacity for public learning. International Social Science Journal, 31(4), 682-695.

Schön, D. A. (1983). The reflective practitioner: How professionals think in action. New York: Basic Books.

Shipton, H. (2006). Cohesion or confusion: towards a typology of organizational learning research. International Journal of Management Reviews, 8(4), 233-252.

Tosey, P., Visser, M., \& Saunders, M. N. K. (2012). The origins and conceptualizations of triple-loop learning: a critical review. Management Learning, 43(3), 291-307.

Van Creveld, M. (2002). The sword and the olive: A critical history of the Israeli Defense Force. New York: Public Affairs. 
Van der Knaap, P. (2004). Theory-based evaluation and learning: possibilities and challenges. Evaluation, $10(1), 16-34$.

Van Dooren, W. (2011). Better performance management: some single- and double-loop strategies. Public Performance \& Management Review, 34(3), 420-433.

Van Gestel, N., Koppenjan, J., Schrijver, I., Van de Ven, A., \& Veeneman, W. (2008). Managing public values in public-private networks: a comparative study of innovative public infrastructure projects. Public Money and Management, 28(3), 139-145.

Ventriss, C., \& Luke, J. (1988). Organizational learning and public policy: towards a substantive perspective. American Review of Public Administration, 18(4), 337-357.

Visser, M. (2007). Deutero-learning in organizations: a review and a reformulation. Academy of Management Review, 32(2), 659-667.

Visser, M. (2008). Learning under conditions of hierarchy and discipline: the case of the German army, 19391940. Learning Inquiry, 2(2), 127-137.

Visser, M. (2010). Configurations of human resource practices and battlefield performance: a comparison of two armies. Human Resource Management Review, 20(4), 340-349.

Wildavsky, A. (1972). The self-evaluating organization. Public Administration Review, 32(5), 509-520.

Wilson, J. Q. (1989). Bureaucracy: What government agencies do and why they do it. New York: Basic Books.

Zeitlin, J. (2011). Pragmatic transnationalism: governance across borders in the global economy. SocioEconomic Review, 9(1), 197-206.

Max Visser is currently an associate professor at the Institute for Management Research, Radboud University, the Netherlands. His research interests include the relation between organizational learning, management control and performance, in particular in public and governmental organizations. Further, he is interested in the relations between governance, performance and behavior in organizations, increasingly from a Critical perspective.

Kim Van der Togt is currently an attorney at law at DLA Piper, Amsterdam, the Netherlands. She graduated in Criminal Law and in Business Administration (Radboud University), and in Criminology and Criminal Justice (University of Oxford, UK). 